\title{
11 Corruption and Countervailing Action in Pakistan
}

\author{
M. Shahid Alam*
}

NORTHEASTERN UNIVERSITY, BOSTON, MASS.

\section{INTRODUCTION}

In this chapter I present some preliminary results on the nature of corruption and countervailing action in Pakistan, drawing on data extracted from newspapers. Once it is recognized that corruption creates losers as well as winners, some dramatic implications for the theory of corruption emerge. This leads to an analysis of the countervailing action taken by losers to offset their losses from corruption. Countervailing action may take several forms. Direct action is perhaps the most effective, as it operates by reducing the net gain from corruption. An examination of the instruments of direct action (including various forms of protest, legal action, political action, and propagating reports on corruption) shows that it often generates press reports on corruption, especially where the press is relatively free; both the losers and other agents will put pressure on the newspapers to provide coverage of both the corruption and direct action. Because pressure emanates from many different sources, it is expected that the coverage of corruption and the direct action will be comprehensive. The analysis of data extracted from three newspapers in Pakistan, covering the period January-February 1994, supports this thesis. Before presenting any empirical results however we analyse the concept of countervailing action, and examine the relative merits of the different sources of data on corruption and countervailing action.

\section{THE THEORY OF COUNTERVAILING ACTION}

Corruption nearly always creates both winners and losers. Alam (1989) discusses how existing theories of corruption have focused attention 
almost exclusively on winners, and concluded that variation in corruption depends on the size of governments, market intervention, the internal structure of bureaucracies and value systems. A rather different analysis of the causes of corruption emerges from Alam (1995), where corruption is examined from the perspective of the losers.

When the losses from corruption are visible to the losers, they may engage in three types of countervailing action: evasive, direct, or illicit. The first two are defined in terms of their effects: evasive action reduces the gross gains from corruption, while direct actions raise the costs of engaging in corruption, thereby lowering net gains from corrupt acts. ${ }^{1}$ Illicit action can be defined in terms of the means employed to fight corruption, since corruption is used to offset the losses from corruption.

The concept of direct action may easily be extended to include actions which do not emanate from victims, but have the same effects. A list of these alternative sources of direct action might include civil associations (such as labour unions, human rights groups, sports clubs, neighbourhood groups and professional associations), trade associations, honest officials seeking to combat corruption in their agencies, winners who have fallen out among themselves, governments making revelations of corruption about their predecessors or vice versa, and newspapers. Unless specified, all sources of direct action will be subsumed in this concept.

The choice of countervailing action, and its effectiveness, depends on two different sets of factors. The first set encompasses property rights broadly interpreted, together with the institutions which sustain these rights. These maybe described as global factors because they can affect the ability to engage in countervailing action across a range of corrupt activities. The nature of these property rights depends on the division of the powers of government both horizontally and vertically, the nature of the electoral process, the division of economic activities between public and private actors, the extent of press freedoms, levels of income and education, the distribution of assets and incomes, and technologies of communication and transportation. ${ }^{2}$ Variations in corruption over time and across countries may be explained in large part as flowing from differences in these global factors. ${ }^{3}$

The ability to engage in countervailing action is sensitive to several factors that are specific to corrupt activities. These include the characteristics of the losers (how many, their age, income and education); the type of government agency (whether its functions are decentralized); the types of service offered by the agency (whether these services 
have any close substitute); the nature of corruption (whether it is coercive or collusive); and the nature of the losses from corruption (whether they are large or small, direct or implicit). Corruption is defined as collusive when all persons connected to the corrupt act collude in the act of corruption. It is coercive when at least one of the persons directly connected with the corruption is subject to coercion. Variations in corruption across government agencies and their sub-units may be largely explained in terms of different combinations of these specific factors.

\section{SOURCES OF DATA}

An empirical study of corruption, including countervailing action, can draw upon three sources of data: case studies of corrupt agencies; questionnaire-based surveys; and reports of corruption in published sources, including newspapers. Wade (1982) and Oldenberg (1987) have presented excellent case studies, while Rose-Ackerman (1978) frequently uses news reports for illustrative purposes.

Case studies can furnish insights into the scale, mechanisms and effects of corruption in specific agencies. A portfolio of such studies, covering a variety of government agencies, may also help to present a larger picture about overall levels of corruption; when undertaken periodically, they can also be used to monitor the movement of corruption in specific agencies. Case studies, however, are difficult to carry out because they require time and patient detective work. Surveys are easier to implement but suffer from several biases in coverage. Data gathered from the victims of corruption are likely to be skewed towards coercive corruption so that cases of collusive corruption will remain invisible and unreported. The beneficiaries of collusive corruption are unlikely to implicate themselves, so in general, this means that surveys will reveal few cases of high-level corruption, which is often both collusive and invisible. Furthermore, surveys are unlikely to provide any deeper insight into the internal dynamics of corrupt agencies.

Assuming that newspapers enjoy freedom of speech and are competitive, one would expect them to provide comprehensive coverage of corruption and any direct action. First, there are the victims of corruption and voluntary groups working on their behalf; these are likely to generate reports of coercive corruption and collusive corruption with direct losses. Other sources are more likely to generate reports on collusive corruption with no direct victims: such as, winners who have 
fallen out among themselves; honest officials seeking to combat corruption in their agencies; governments revealing corruption by their predecessors or vice versa, and investigative journalism competing for readership. However, news reports have one unavoidable flaw: for reasons to be explained later, they are unlikely to carry reports on evasive and illicit actions.

It must be emphasized that if newspapers are to cover corruption comprehensively they must be free from official censorship, and from intimidation by powerful groups, who gain from corruption. The coverage of corruption will also be compromised where newspapers are owned by the corrupt groups or collude with them. A free and competitive press - where several newspapers compete for the same readership may help to minimize some of these risks, but in the final analysis the degree of free coverage given to corruption can only be ascertained by empirical analysis of news reports on corruption.

\section{CORRUPTION IN PAKISTAN}

The analysis of corruption in Pakistan is based on reports drawn from three newspapers published in Karachi, covering the period JanuaryFebruary 1994 - a period when the press in Pakistan was partially free and competitive. ${ }^{4}$

This empirical analysis of corruption is based on the frequency of reports on corruption, not on the number of corrupt acts. ${ }^{5}$ Most reports on corruption describe single acts of corruption (for example, a murder in police custody), but sometimes they also describe a class of corrupt acts (for example, officially collusion with farmers in understating the number of functioning tube wells). More important, since the nature of corrupt acts varies across government agencies, nothing would be gained from an analysis that treated these corrupt acts as homogeneous.

We obtained 329 reports on corruption from the three newspapers during January and February of 1994: 139 from The News, 86 from Dawn, and 104 from Jang. Assuming that these figures were sustained over the year, one might have expected 2000 reports on corruption in Pakistan during 1994. This would be a large data set by the standards of most research in the social sciences, and one that could easily be expanded. And yet, to our knowledge, the potential they offer for the systematic study of corruption has remained unutilized.

What do these reports suggest about the pervasiveness of corruption, the types of corruption, and their distribution across different levels 
Table 11.1 Frequency of reports on corruption: by level of government and type of corruption

\begin{tabular}{|c|c|c|c|c|}
\hline Newspaper & $\begin{array}{c}\text { Level of } \\
\text { government }\end{array}$ & Collusive & $\begin{array}{c}\text { Reports published } \\
\text { Jan-Feb } 1994 \\
\text { Coercive }\end{array}$ & Total \\
\hline News & $\begin{array}{l}\text { Local } \\
\text { Provincial } \\
\text { Federal } \\
\text { All }\end{array}$ & $\begin{array}{l}11 \\
31 \\
28 \\
70\end{array}$ & $\begin{array}{r}2 \\
43 \\
24 \\
69\end{array}$ & $\begin{array}{r}13 \\
74 \\
52 \\
139\end{array}$ \\
\hline Dawn & $\begin{array}{l}\text { Local } \\
\text { Provincial } \\
\text { Federal } \\
\text { All }\end{array}$ & $\begin{array}{r}6 \\
21 \\
16 \\
43\end{array}$ & $\begin{array}{r}5 \\
28 \\
10 \\
43\end{array}$ & $\begin{array}{l}11 \\
49 \\
26 \\
86\end{array}$ \\
\hline Jang & $\begin{array}{l}\text { Local } \\
\text { Provincial } \\
\text { Federal } \\
\text { All }\end{array}$ & $\begin{array}{r}6 \\
30 \\
15 \\
51\end{array}$ & $\begin{array}{r}4 \\
42 \\
7 \\
53\end{array}$ & $\begin{array}{r}10 \\
72 \\
22 \\
104\end{array}$ \\
\hline All & $\begin{array}{l}\text { Local } \\
\text { Provincial } \\
\text { Federal } \\
\text { All }\end{array}$ & $\begin{array}{r}23 \\
82 \\
59 \\
164\end{array}$ & $\begin{array}{r}11 \\
113 \\
41 \\
165\end{array}$ & $\begin{array}{r}34 \\
195 \\
100 \\
329\end{array}$ \\
\hline
\end{tabular}

of government? A careful comparison of the reports of corruption from the three newspapers revealed very little overlap in their coverage. There were ten overlapping reports in Dawn and The News; eleven in The News and Jang; and four in Dawn and Jang. The number of corrupt acts would have to be very large indeed to account for the very low level of overlapping reports published by the three newspapers. The large number of reports describing patterns of corruption paint a picture of pervasive corruption in many government agencies.

The reports on corruption are distributed unevenly across the three levels of government. Table 11.1 shows that corruption in local, provincial and federal governments accounted for 10 per cent, 59 per cent and 30 per cent, respectively, of all reports on corruption. One should, however, be careful in interpreting these numbers. Local government in Pakistan has very limited functions and budgets, and this, perhaps, accounts for their small share in the reports of corruption. Federal agencies, on the other hand, command the largest share of total government expenditure but account for only 30 per cent of all reports on corruption. ${ }^{6}$ This is probably due to the collusive nature of much of the corruption (often with hidden losses) in federal agencies, making 
direct action by losers difficut. Even when such losses are visible, the cost of mounting direct action is likely to be high in this case; the ruling elites are likely to be sensitive to reports of corruption in branches of the federal government, because of its greater capacity for political damage, something newspapers would be the first to know. ${ }^{7}$ In comparison, reporting on corruption in provincial governments is less constrained. The high provincial share in reports on corruption also reflects the fact that policing is a provincial subject, and coercive corruption in policing provokes a great deal of direct action.

A comparison of the reports on collusive and coercive corruption in Table 11.1 supports the thesis that when the press is free and competitive, its coverage of corruption is likely to be comprehensive. Close to half of the reports refer to collusive corruption, although this ratio varies for the three levels of government. Collusive corruption accounts for two-thirds of the reports at the level of local government, nearly three-fifths at the level of federal agencies, and two-fifths at the level of provincial governments. The lower proportion of reports on collusive corruption in provincial agencies is explained by the high incidence of coercive corruption in the security agencies, which are controlled by the provincial governments.

There exist strong similarities in the patterns of corruption reported by the three newspapers. For each newspaper, the share of reports on coercive corruption ranged from 2 per cent to 12 per cent for local government, 62 to 79 per cent for provincial governments, and 13 per cent to 35 per cent for the federal government. Similarly, the reported shares of collusive corruption ranged from 12 per cent to 16 per cent for local government, 44 to 59 per cent for provincial governments, and 29 per cent to 40 per cent for the federal government. These similarities are also observed in the distribution of corruption across agencies. An explanation for these similarities might be offered in terms of a heuristic model in which newspapers as private business engage in rationing a scarce resource - access to their readership - among a diverse array of constituents, including the victims of corruption; human rights and community groups; disgruntled factions among the winners from corruption; the government and other political parties, all of whom lobby for newspaper space. The rationing decisions are guided by the profit motive - which depends on readership and revenue from advertising - tempered by the need to strike a balance among these diverse and opposite constituents. Similarities in their readership clusters, business interests, and the outside groups making demands on their space, will tend to produce similar rationing decisions. All three newspapers in 
Table 11.2 Frequency of reports on corruption: by government agency/ office and type of corruption

\begin{tabular}{lccc}
\hline & \multicolumn{3}{c}{ Reports of corruption } \\
Agency/office & Collusive & Coercive & All \\
\hline KMC & 10 & 11 & 21 \\
Other LGs & 13 & 0 & 13 \\
City agencies & 17 & 3 & 20 \\
Security agencies & 29 & 89 & 121 \\
Other state agencies & 40 & 25 & 65 \\
Other federal agencies & 33 & 16 & 49 \\
State-owned banks & 7 & 3 & 10 \\
PM's Office & 4 & 6 & 10 \\
CM's Office & 7 & 5 & 12 \\
Members & 4 & 4 & 8 \\
All & 164 & 165 & 329 \\
\hline
\end{tabular}

Notes: KMC: Karachi Municipal Corporation; LGs: local governments; City Agencies: Karachi Development Authority (KDA), Karachi Electric Supply Corporation (KESC) and Karachi Road Transport Corporation (KRTC); Security: Includes police (including traffic police), Central Investigation Agency (CIA), Federal Investigation Agency (FIA), PM: Prime Minister; CM: Chief Minister; Members: Members of federal and provincial legislatures (including ministers).

Sources: The News; Dawn; Jang.

our study are based in Karachi, have a national focus, and are privately owned without any political party affiliation. These common factors probably account for the similarities in reporting patterns described earlier.

A more disaggregated analysis of the reports on corruption is given in Table 11.2, where the reports on corruption are allocated to ten groups of agencies and offices. ${ }^{8}$ The security agencies account for more than a third of all the reports on corruption, and more than half of all the reports on coercive corruption, which include murder, torture, rape, illlegal detention, illegal entry, and forcible expropriation. Some crimes were committed at the behest of the federal and provincial governments, but more often the security agencies act in collusion with local power hierarchies or on their own.

There are many reports of corruption at the highest echelon of all three levels of government. The two highest offices in the federal government and four provincial governments - prime minister and chief ministers - were cited in twenty-two reports of corruption, equally divided 
between coercive and collusive corruption. Eight of the reports of corruption implicated federal and provincial legislators; and ten reports were of corruption in state-owned banks. Because of the caution that newspapers must exercise in reporting corruption in the highest offices, these reports may understate the incidence of corruption at these levels of government.

\section{COUNTERVAILING ACTION}

While countervailing action against corruption may take different forms - including direct, evasive, and illicit acion - clearly only direct action is likely to be reported in newspapers. In general, evasive action is likely to be taken individually, and is unlikely to attract attention outside the corrupt agencies. For example, faced with corruption, individuals may decide to relocate, forgo any transaction involving corruption, seek out officials who are not corrupt, find substitutes for the services provided by corrupt officials, or act to reduce their vulnerability to corrupt officials. These actions would be unlikely to strike anyone as newsworthy.

One encounters a different problem with respect to illicit action. This differs from corruption per se, not in its form, but in its intent and effects; and since intentions and effects are difficult to observe, reports of illicit action are likely to be lumped together with corruption. Furthermore, people who engage in illicit action are not likely to seek redress through publicity. Had publicity been a viable solution they might have sought it in the first place. Not surprisingly, then, careful sifting of the reports on corruption offered no evidence of evasive or illicit action, leaving only the analysis of direct action. The direct action reported by newspapers was analysed from two perspectives. First, the sources of direct action were sorted by type of corruption and the agencies targeted. Second, the instruments of direct action by type of corruption were analysed.

Direct action may arise from six sources: (i) individual direct action by the victims of corruption; (ii) collective direct action by the victims of corruption; (iii) collective direct action by others acting on behalf of victims, including human rights organizations, community organizations, or political parties; (iv) direct action by government agencies, often in response to direct action from other sources; (v) direct actions by disgruntled winners; and (vi) a residual category, newspapers, that might include investigative reports by the newspapers, leaks 
Table 11.3 Sources of countervailing actions; by type of corruption

\begin{tabular}{lllllllll}
\hline & & \multicolumn{7}{c}{ Source } \\
\cline { 3 - 9 } $\begin{array}{c}\text { Paper } \\
\text { Jan-Feb } \\
\text { 1994 }\end{array}$ & $\begin{array}{c}\text { Type of } \\
\text { corruption }\end{array}$ & $\begin{array}{c}\text { Individual } \\
\text { DA by } \\
\text { victims }\end{array}$ & $\begin{array}{c}\text { Collective } \\
\text { DA by } \\
\text { victims }\end{array}$ & $\begin{array}{c}\text { Collective } \\
\text { DA by } \\
\text { others }\end{array}$ & $\begin{array}{c}\text { DA by } \\
\text { losing } \\
\text { factions }\end{array}$ & $\begin{array}{c}\text { DA by } \\
\text { government } \\
\text { agency }\end{array}$ & $\begin{array}{c}\text { News } \\
\text { paper }\end{array}$ & total \\
\hline The News & Collusive & 6 & 3 & 5 & 0 & 26 & 21 & 61 \\
& Coercive & 23 & 10 & 7 & 1 & 15 & 13 & 69 \\
& All & 29 & 13 & 12 & 1 & 41 & 34 & 130 \\
Dawn & Collusive & 3 & 6 & 0 & 0 & 22 & 4 & 33 \\
& Coercive & 22 & 22 & 4 & 2 & 12 & 3 & 65 \\
\multirow{5}{*}{ Jang } & All & 25 & 28 & 4 & 2 & 34 & 7 & 98 \\
& Collusive & 2 & 7 & 4 & 1 & 24 & 4 & 42 \\
& Collusive & 25 & 14 & 7 & 0 & 16 & 6 & 68 \\
& All & 27 & 21 & 11 & 1 & 40 & 10 & 110 \\
& Collusive & 11 & 16 & 9 & 1 & 72 & 29 & 138 \\
& Coercive & 70 & 46 & 18 & 3 & 43 & 22 & 202 \\
& All & 81 & 62 & 27 & 4 & 115 & 51 & 340 \\
\hline
\end{tabular}

Note: 1. DA: direction action. In some cases corruption evokes DA from multiple sources.

from disgruntled winners, leaks from government, or honest insiders, and information from victims not identified in the reports.

The distribution of direct action by source, type of corruption and newspapers is presented in Table 11.3. We have reports on 340 cases of direct action, distributed unevenly across the different sources. ${ }^{9}$ Direct action by victims and their allies accounted for 170 cases of direct action; more than half of them involving collective action, pointing to the emergence of civil associations, actively seeking to limit state abuses. Further, since overlaps among the three newspapers were very low, the reported cases of direct action by victims probably represent only a small fraction of the universe of direct action. At the very least, then, this suggests that a significant number of victims of corruption are actively seeking to reverse their losses.

More than a third of all direct action emanates from a government source. The motivation for such action may have its origin in different sources. A government that seeks votes must show solicitude for the general concern about corruption in government. This can most conveniently be done by publicizing corruption in the previous, rival government. It is possible that this could be in response to the direct action by victims, although this could only be verified in a small number of reports. ${ }^{10}$ Some government action was aimed at the recovery of utility charges by one government agency from another, possibly under pressure from international funding agencies. Nevertheless, whatever 
Table 11.4 Instruments of direct action, by type of corruption

\begin{tabular}{llrrrrrr}
\hline & & \multicolumn{7}{c}{ Instruments } \\
\cline { 3 - 8 } $\begin{array}{c}\text { Paper } \\
\text { Jan-Feb }\end{array}$ 1994 & $\begin{array}{c}\text { Type of } \\
\text { corruption }\end{array}$ & Protests & $\begin{array}{c}\text { News } \\
\text { reports }\end{array}$ & $\begin{array}{c}\text { Legal } \\
\text { action }\end{array}$ & $\begin{array}{c}\text { Investigative } \\
\text { report }\end{array}$ & $\begin{array}{c}\text { Official } \\
\text { punitive } \\
\text { action }\end{array}$ & Total \\
\hline \multirow{2}{*}{ The News } & Collusive & 12 & 7 & 5 & 22 & 11 & 57 \\
& Coercive & 7 & 15 & 25 & 16 & 4 & 67 \\
& Total & 19 & 22 & 30 & 38 & 15 & 124 \\
Dawn & Collusive & 16 & 1 & 1 & 3 & 19 & 40 \\
& Coercive & 13 & 1 & 11 & 3 & 9 & 37 \\
\multirow{5}{*}{ Jang } & Total & 29 & 2 & 12 & 6 & 28 & 77 \\
& Collusive & 13 & 1 & 0 & 5 & 23 & 42 \\
& Coercive & 27 & 4 & 16 & 7 & 12 & 66 \\
& Total & 40 & 5 & 16 & 12 & 35 & 108 \\
& Collusive & 41 & 9 & 6 & 30 & 53 & 139 \\
& Coercive & 47 & 20 & 52 & 26 & 25 & 170 \\
& Total & 88 & 29 & 58 & 56 & 78 & 309 \\
\hline
\end{tabular}

the motivation, these actions impose real costs on corrupt officials, including negative publicity, legal proceedings, suspension and, in a few cases, imprisonment.

Table 11.3 also reveals a significant contrast in the pattern of direct action. Direct action by victims and their allies occurs mainly in response to coercive corruption: more than three-quarters of this direct action was directed against coercive corruption. On the other hand, three-fifths of the direct action by government agencies and newspapers was targeted against collusive corruption. This asymmetry is what we might expect, since coercive corruption is generally more visible to victims, while governments and newspapers have inside information on collusive corruption not always available to victims.

Direction action can take several forms. An examination of Table 11.4 shows that protest (88 reports) was the most frequently chosen instrument of direct action, followed by official punitive action (78 reports), legal action (58 reports), investigative reports (56 reports), and news reports initiated by losers, their allies and others (29 reports). It is worth noting that the use of these instruments varies with the type of corruption. Legal action and news reports arise more often in response to coercive corruption; official punitive action is more frequently reported over collusive corruption; and protests and investigative news reports are distributed fairly evenly across the two types of corruption. 


\section{CONCLUDING REMARKS}

My primary objective has been to explore the potential for empirical analysis of corruption and countervailing action, based on data extracted from newspapers. Theoretical analysis suggests that when the press is free and competitive, it is likely to cover corruption and direct forms of countervailing action comprehensively.

This theory is borne out by data collected from three Pakistani newspapers published during January and February 1994. The exercise yielded a large number of reports on corruption, distributed evenly between collusive and coercive types of corruption. Since overlapping reports were few, this suggests that the total range of corrupt acts must be very large. When combined with a large number of reports which establish patterns of corruption, this points to the presence of pervasive corruption at all levels of government in Pakistan.

More important, we also extracted 340 cases of direct action from these news reports. Direct action by victims and their allies constituted half of the reported direct action, and more than half of these took the form of collective action, suggesting that civil society is active in fighting the abuses of government. The government itself emerged as the single largest source of direct action. While direct action by government agencies may have different motives, we suggest that much of it is in direct response to the direct action of victims.

We conclude with a warning about the tentative nature of these findings, based as they are on news reports relating to a short time period. There is a need to expand the data set by scanning more newspapers and over a longer time period. To gain a comparative perspective, these studies might be extended to other countries with different degrees of press freedom. Finally, the analytical methods employed here could be refined in future analyses.

\section{Notes}

* The research for this chapter was initiated when I was visiting at the Applied Economics Research Centre, University of Karachi, during 1994-5. I am grateful to Sikander Mehmood, project economist, for his help.

1. Losers engage in evasive action when they relocate (to escape extortion), seek out officials who are not corrupt, find substitutes for goods or services provided by corrupt officials, forgo such goods and services altogether, or take actions which reduce their dependence on corrupt officials. 
2. The impact of global factors on countervailing actions is mediated through the visibility of corrupt activities, the range of instruments available for direct and evasive action, and the effectiveness of these instruments.

3 . It is often argued that corruption varies with the size of government. This is true only if all other factors are held constant. Growth in government expenditure and regulation may not lead to rising corruption if the tendencies to corruption they create are offset by even stronger countervailing forces. Proof of this may be found in the history of Western democracies since the nineteenth century, a period when they experienced both a growth in government and a decline in levels of corruption.

4. Pakistan has been ranked as partially free (in a ranking system that includes free, partially free and not free) since 1986, in McColm (1991).

5 . Where $n$ agencies are cited in any report on corruption, a single report leads to $n$ entries, one for each agency cited in the report. A report on corruption was entered into our data set only when the following information was available or could be inferred: (i) the nature of the corrupt act or class of corrupt acts; (ii) the agencies involved (federal, provincial, or local); (iii) the source(s) of countervailing action; and (iv) the instrument(s) of countervailing action.

6. It should be noted that although the federal agencies account for about a third of all reports on corruption, a much higher proportion of these reports points to patterns of corruption in different agencies, endorsing a picture of pervasive corruption.

7. The largest branch of federal government, the country's military establishment, is off-limits to newspapers.

8. All branches of local government in Karachi have been aggregated under Karachi Municipal Corporation (KMC). KMC is responsible for water supply, sanitation and road repairs, and runs some schools and hospitals; it also collects some local taxes. Local government in all areas outside Karachi has been lumped together under 'Other LGs'. City Agencies include four agencies: Karachi Development Authority (KDA); Karachi Port Trust (KPT); Karachi Electric Supply Corporation (KESC); and Karachi Road Transport Corporation (KRTC) - all of them are run by the provincial government. The Security Agencies include the police departments (including the traffic police); the Central Investigation Agency (CIA); the Federal Investigation Agency (FIA); and Airport Security Force (ASF). The first two are provincial agencies, the latter two are federal agencies. A chisquare test rejected at the 1 per cent level the null hypothesis that the distribution of corrupt acts across different agencies is independent of the type of corruption.

9. In some cases, a single act of corruption generated multiple direct actions, each of which was recorded separately. On the other hand, we do not count the newspapers as a source of direct actions when some other source is identified by the report.

10. In order to determine whether government actions were in response to direct action from victims, our analysis would have to cover reports spanning a longer period of time. 


\section{References}

Alam, M. S. (1989) 'Anatomy of Corruption: An Approach to the Political Economy of Underdevelopment', American Journal of Economics and Sociology, vol. 48, no. 4, pp. 441-56.

Alam, M. S. (1995) 'A Theory of Limits on Corruption and Some Applications', Kyklos, vol. 48, no. 3, pp. 419-35.

Mauro, P. (1995) 'Corruption and Growth', Quarterly Journal of Economics, vol. 110, no. 3, pp. 681-712.

McColm, R. B. (1991) Freedom in the World: Political Rights and Civil Liberties (New York: Freedom House).

Oldenburg, P. (1987) 'Middlemen in Third World Corruption: Implications for an Indian Case', World Politics, vol. 39, pp. 508-35.

Rose-Ackerman, S. (1978) Corruption: A Study in Political Economy (New York: Academic Press).

Wade, R. (1982) 'The System of Administrative and Political Corruption: Canal Irrigation in South India', Journal of Development Studies, vol. 18, pp. 287-328. 